\title{
БАЛКАНСКИЙ ПОЛУОСТРОВ: ОСОБЕННОСТИ ГЕОПОЛИТИЧЕСКИХ И МЕЖНАЦИОНАЛЬНЫХ ПРОЦЕССОВ
}

\begin{abstract}
Аннотация
Статья посвящена рассмотрению социально-политических процессов, происходящих на Балканском полуострове в историческом и современном аспекте. Автор рассмотрел основные проблемные вопросы в сфере геополитических и межнациональныхпроцессов на Балканах. Приведены отрицательные факторы, мешающие развитию стран Балканского полуострова на современном этапе. Проанализированы тенденции интеграции балканских стран в европейское сообщество и представлены перспективы решения «балканского вопроса».
\end{abstract}

Ключевые слова: страны Балканского полуострова, полиэтническое государство, межэтнические конфликты, евроинтеграция.

DOI: 10.51180/RPS.2021.18.1.007

\section{Автор}

\section{Ламаш Максим Викторович}

Бакалавр политических наук, студент магистратуры

по направлению «Юриспруденция»

в Seton Hall Law

(Ньюарк, США)

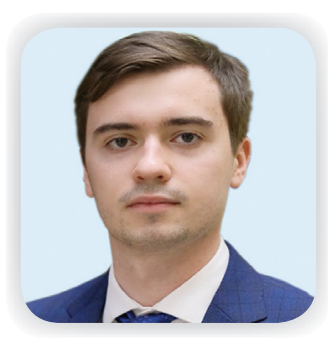

\section{Введение}

дним из регионов, который претерпел существенные геополитические трансформации на границе конца XX - начала XXI в. и сегодня остается наиболее нестабильным в Европе, являются Балканы. Ряд событий, которые происходили на протяжении длительного исторического времени в Балканском регионе с эпохи Оттоманской империи, способствовал закреплению в массовом сознании и в политических кругах его негативного образа как «порохового погреба» Европы, наравне с иными восточными странами. По обычаям, культуре, уровню жизни балканские страны отличаются от западноевропейских, так как имеют низкую политическую культуру, разобщены, находятся в состоянии постоянного конфликта друг с другом и не способны самостоятельно решать важные проблемы региона [1]. Поэтому термин «балканизация» [2] стал неким синонимом крайней раздробленности, несобранности региона. Государствам Балканского полуострова свойственно противоречивое сочетание современности с прошлым, что ведет к появлению социально-экономической и политической многоукладности, обострению и наложению внутренних разнородных конфликтов, которые в конце концов ведут к процессам перераспределения границ и образования новых независимых государств. В частности, это касается проблемы определения статуса Косово и урегулирования межэтнических и региональных противостояний. Здесь проходит наиболее неустойчивая, размытая граница между христианской и мусульманской цивилизациями - снестабильностью, высокой конфликтностью различных этносов, конфессий. Межэтнические и религи- 
озные конфликты на Балканах часто не признают государственных границ, втягивая в себя другие, не принадлежащие Балканам страны и международные организации, что частично подтверждает концепцию «цивилизационного разлома» С. Хантингтона [3].

Для современных Балкан характерными остаются политическая напряженность во взаимоотношениях между странами, продолжительность межэтнических споров, тенденция активизации национально-радикалистских движений.

Научный интерес к Балканам определяется их местом в жизни Европы как в прошлом, так и в будущем. Главными центрами напряжения на Балканах и в Европе в целом в девяностые годы XX в. стали Босния и Косово. Уменьшение напряженности внутри данных районов потребовало вмешательства многих государств, международных организаций, включая силы НАТО. В этом случае имели место не только европеизация Балкан, но и балканизация Европы [4]. Понятно, что политики и ученые задаются вопросом, насколько прочным окажется хрупкий мир, поддерживаемый Дейтонскими соглашениями, и не постигнет ли их судьба Версальского договора?

Балканский контекст остается актуальным и сегодня, потому что он не только является зоной повышенной межэтнической конфликтности и постоянной конфронтации интересов крупных геополитических игроков (США, ЕС, Россия), но и может стать опытом, полезным для любого европейского государства с точки зрения интеграции в европейские и евро-атлантические структуры.

Ход событий в течение последних десятилетий на Балканах необходимо рассматривать, во-первых, с точки зрения взаимодействия как центростремительных, так и центробежных тенденций, которые проявляются на фоне событий XX - начала XXI в.; во- вторых, в контексте изменений геополитической ситуации в мире; в-третьих, сучетом специфики политико-экономических отношений и межнационального развития в данном регионе.

Исторический опыт развития современного мира убедительно свидетельствует о действии двух противоположных тенденций: с одной стороны, интеграции государств, с другой постоянного возникновения новых государственных образований. Трудно не согласиться с французским исследователем П. Бонифасом, что мы живем в век распада [5]. В 1990-е годы наблюдался эффект матрешки, когда большие федерации (СССР, СФРЮ и ЧСФР) распадались на отдельные государства. Увеличение количества государств иногда связано с распространенным представлением о том, что создание собственных государств - это путь к решению проблем современности. Именно в этом заключается одна из самых серьезных и злободневных проблем, с которыми столкнется мировое сообщество в XXI в., ведь дальнейшее увеличение количества государств может привести к нарушению порядка на международной арене, так как новые государства преимущественно, скорее всего, окажутся политико-экономически слабыми. Наиболее вероятным претендентом на дальнейшее дробление вследствие обострения языковых, этнотерриториальных, религиозных противоречий и экономических различий между его частями остается Балканский регион.

Современные Балканы представляют собой зону стратегического контроля, где сталкиваются интересы великих держав, ведь их геополитическая позиция (расположение на стыке трех континентов и выход к Адриатическому, Черному, Эгейскому и Ионическому морям) дает широкие возможности геостратегического сотрудничества. Как несколько веков назад за господство в этом регионе шли войны, так и 
сегодня идет борьба за экономические и политические интересы. Наличие там практически крупнейшего в Европе хранилища полезных ископаемых гидротермальных месторождений свинцово-цинковых руд, меди, сурьмы, молибдена - всегда делало Балканы одним из основных центров притяжения для европейских государств. Пока же подступы к СредиземноморскоЧерноморскому бассейну становятся стратегически еще более значимыми с точки зрения доставки энергоресурсов. Внешнеполитические усилия Евросоюза направлены на утверждение себя в качестве мощного регионального игрока. Присутствуют здесь также интересы, а значит, и рычаги влияния Североатлантического альянса. На данный момент окончательно сформировались позиции всех ключевых геополитических игроков в регионе - ЕС, США и России. По нашему мнению, дезинтеграционные процессы, происходящие в последние годы в Балканском регионе, являются геостратегией США, которые стремятся не допустить интеграции балканских стран в европейские структуры, а следовательно, и контроля над ними со стороны ЕС. С другой стороны, США хотят «вытеснить» отсюда Россию, для которой Балканы - это регион, где ее внешняя политика традиционно не только учитывала этнический и религиозный факторы, но и эффективно использовала их. Для США важно как ослабить позиции Российской Федерации на Балканах, так и «подарить» Европе долгосрочный очаг напряжения, который сделает невозможным превращение ЕС в мощный геополитический центр силы.

В свое время экономическая и военно-политическая мощь Советского Союза была основным сдерживающим фактором против любых попыток пересмотра мироустройства, сложившегося после Второй мировой войны, и обеспечивала баланс сил и интересов ведущих мировых стран. Распад СССР стал толч- ком для цепной реакции «этнического ренессанса» в Югославской федерации. К выходу из ее состава Хорватии и Словении в 1991 г. привели национальные амбиции, обиды, которые накапливались на протяжении столетий, активное разжигание межнациональных конфликтов странами католического и мусульманского мира. При этом был создан опасный прецедент нарушения принятого ОБСЕ порядка послевоенного устройства Европы с пренебрежением к конституционно-правовой системе Югославии. При поддержке стран Североатлантического альянса из ее состава в 1992 г. вышла мусульмано-хорватская Босния и Герцеговина. К декабрю 1998 г. волна сепаратизма захлестнула автономный край Косово, населенный преимущественно мусульманами. Однако вместо мирного урегулирования межэтнических противоречий страны члены НАТО решились на силовое решение косовской проблемы [6].

Вследствие дробления федеративного пространства образовались минигосударства, в большинстве которых пока отсутствует стабильность политических институтов, обеспечивающих демократическое развитие; налицо нерешенные вопросы взаимоотношений титульных наций и национальных меньшинств, проблема соблюдения прав человека; в ряде стран потеряна часть политического суверенитета и установлены протектораты в различных формах. Внутренняя ситуация в каждой из стран бывшей Югославии по-прежнему влияет на межэтнические отношения на всем постъюгославском пространстве и на региональную стабильность. Сегодня комплекс отношений между странами Балканского региона не исчерпывается вопросами соблюдения принципа нерушимости границ, нарушением прав и свобод человека. На Балканах значительную роль играют и такие факторы, как историческая память, ввод в действие законов, ограничивающих гражданские 
и политические права недоминирующих этноменьшинств и т.д. На массовое сознание балканских народов до сих пор влияет ощущение исторической несправедливости, которое выразилось в разделении наций, урезании территории страны. Эти настроения иногда подогреваются официальными и академическими кругами, средствами массовой информации внутри самих стран. Загреб и Белград объективно являются не только «историческими соперниками», но и политическими оппонентами, а Босния и Герцеговина своеобразной "точкой соприкосновения» их влияния. Северная Македония и Косово остаются главными «проблемными точками» в регионе.

Несмотря на взаимозависимость противоречий на современном балканском пространстве, каждое из них имеет свою природу, темпы развития, формы и методы решения, специфика которых обусловлена мощным влиянием различных факторов.

\section{Исторические и геокультурные факторы}

Современные Балканы представляют собой довольно сложную модель исторического и политико-культурного развития, которая конструировалась как на почве собственных вековых традиций, так и под влиянием Востока и Запада. В определенной степени они являются "пространством между Востоком и Западом", но их историческая, географическая и культурно-цивилизационная принадлежность к Европе - неоспоримый факт. В течение длительного времени здесь смешивались разные национальные идеи, религии и культуры, повлекшие конфликтный характер развития балканских народов и разногласия внешнеполитических приоритетов на том же историческом отрезке. Все это в конечном итоге сформировало особенности балканского менталите- та и способствовало укоренению неуверенности и страха в коллективном бессознательном этих народов. Они были вынуждены постоянно бороться за сохранение своих религии, языка и культуры и даже защищать собственное физическое существование. Отсюда исключительная чувствительность к событиям и явлениям, которые могут угрожать их самобытности, территории или государству. Это объясняет, почему западным наблюдателям и исследователям, исповедующим принципы западного рационализма, трудно понять поведение балканских народов и их «непредсказуемую реакцию». Безусловно, все это необходимо иметь в виду при поисках формулы восстановления мира на Балканах.

Формирование национального сознания народов Балканского региона, находившегося в составе империй (с IV в. - Римской и Византийской, с XIV - Оттоманской), происходило под влиянием христианского и мусульманского миров, которое сказалось на приверженности большинства нынешних жителей Балкан к православию, при одновременном распространении ислама. Иными словами, происходила поляризация в этнорелигиозной самоидентификации балканских народов. Религиозный срез на Балканах обусловлен преимущественно этническим происхождением населения. Болгары, греки, македонцы, сербы, румыны, черногорцы преимущественно исповедуют православие. Однако среди македонского населения из-за наличия немалой группы албанцев $(25,2 \%)$ и турок $(3,9 \%)$ широкое распространение получил ислам, который исповедуют славянемусульмане, турки и большинство населения Албании (70\%). В Боснии и Герцеговине, которые принципиально отличаются от других балканских стран своим крайне сложным и противоречивым историческим развитием, не сформировалась единая нация, а существуют три этнонациональные 
группы: боснийцы-мусульмане (48\%), сербы (37\%) и хорваты (14,3\%). Их религиозные предпочтения соответствуют традиционным вероисповеданиям этих групп (40\% населения - мусульмане, $31 \%$ - православные христиане, 15\% католики). Католицизм распространен среди хорватского и словенского населения. Кроме того, на Балканах мирно сосуществуют протестантизм и иудаизм, который в основном исповедуют национальные меньшинства - немцы, евреи, словаки, чехи, венгры и др. [7].

\section{Этнические и религиозные факторы}

Этническая и религиозная пестрота Балкан вместе со стереотипами, которые наслаивались на протяжении веков, и "живыми воспоминаниями» событий последних лет, наполненными примерами унижения национального достоинства, геноцидом и кровавыми войнами, пока являются скорее фактором деконсолидации. Среди характерных признаков межнационального развития Балкан можно определить следующие:

- нарастание тенденции латентных и открытых межнациональных конфликтов в регионах с полиэтническим составом населения;

- углубление внутренних межнациональных противоречий и их трансляция на межгосударственный уровень;

- непримиримая позиция националистически настроенных сил в отношении «права голоса» других этнических групп, проживающих вместе с ними.

Следует учитывать и то обстоятельство, что Балканы являются в экономическом плане наименее развитым европейским регионом. Босния и Герцеговина, Северная Македония, Черногория отставали в экономическом развитии от Сербии. Это приводило к различиям в доходах различных этнонациональных групп и усиливало противоречия между ними. Экономический кризис, безработица, инфляция, девальвация динара усиливали центробежные тенденции в стране, особенно в начале 1980-х годов. Существенные социально-экономические разногласия между балканскими странами четко прослеживаются и сегодня. Несмотря на определенный прогресс в установлении экономических связей и подписании соглашений о партнерстве и сотрудничестве между странами, до сих пор не сформировано единое экономическое пространство, отмечается медленное осуществление экономических реформ и усиливается зависимость экономического развития от дотаций.

Все это свидетельствует о сохранении сложностей во взаимоотношениях каждой отдельно взятой балканской страны с соседними государствами. По нашему мнению, можно выделить, по крайней мере, три ключевых вопроса, которые сказываются на внутриполитическом развитии Балкан: «македонский вопрос», «албанский национализм» и Косово [8].

Проблема, которая приобрела дискуссионный характер и вышла за рамки двусторонних отношений, - так называемый «македонский вопрос». Болгария первой признала Македонию как независимое государство, однако отрицала факт существования самостоятельных македонских нации и языка, аргументируя эту позицию, прежде всего, языковой близостью и тем фактом, что современная Македония находилась в свое время в составе Болгарии. Этнографы считают македонцев этническими болгарами, такой же точки зрения придерживается и болгарское правительство (македонцы - это болгары, а македонский язык - диалект болгарского). Точка зрения Македонии по этим вопросам прямо противоположная: страна имеет свой национальный язык, культуру и государство. «Языковой конфликт» между двумя государствами быстро распространил- 
ся на политико-правовую сферу, что негативно сказалось на стратегических партнерских отношениях двух стран. Дело дошло до того, что Болгария предложила использовать в двусторонних отношениях в качестве рабочего варианта английский язык. «Потепление» В двусторонних отношениях произошло с признанием Болгарией в 1999 г. существования македонского языка, что было обусловлено преимущественно текущими конъюнктурными соображениями. Однако официальное признание на политическом уровне не означает мгновенных радикальных сдвигов как в общественном сознании, так и во взглядах ученых на эту проблему. Болгарский политикум опасается, что население болгарского Пиринского края также объявит себя македонцами и в стране появится новое нацменьшинство, которое может потребовать национально-культурной автономии, имея покровителя в лице Македонии. Иными словами, резко увеличится количество проблем, с которыми Болгария уже сталкивается из-за наличия в стране турецкого нацменьшинства [9].

Как отношения «повышенной сложности" можно охарактеризовать нынешние македонско-греческие отношения. Зоной постоянной конфронтации между двумя странами с начала обретения Македонией независимости и до 2019 г. является категорическое неприятие Грецией названия страны "Македония" со столицей в Скопье. Именно Греция блокировала вступление Македонии в НАTO и ЕС, аргументируя это тем, что признание международным сообществом названия «Республика Македония" нарушает соглашение о соблюдении добрососедских отношений между двумя странами, поскольку националистические организации в Македонии претендуют на всю территорию древней Македонии. Греческое руководство настаивало на изменениях предыдущего названия бывшей югославской республики за счет внесения в него пояснительного элемента, что позволило бы различать ее с северной исторической областью Македонии, которая принадлежит Греции и составляет более $50 \%$. По мнению ученых и политических кругов Греции, это сделало бы невозможным экспансионистские претензии в будущем и сепарационные тенденции среди населения этой области. Таких же взглядов придерживалось и большинство населения Греции. По данным опроса, проведенного компанией «Паблик Иссью», примерно 95\% греков одобряли вето (по вступлению Македонии в структуры Североатлантического альянса с нынешним названием), к которому прибег премьер-министр Греции на саммите Альянса в Бухаресте. В целом же Македония не воспринималась в общественном сознании как угроза Греции: $68 \%$ греков считали, что соседняя страна представляет «очень малую угрозу», так как, по мнению 90\% респондентов, Македония «нуждается в Греции, чтобы выжить». Однако большая часть греков (7 из 10 опрошенных) была уверена, что "славяно-македонской нации» не существует [10]. В 2019 году республика Македония была переименована в Северную Македонию.

Северная Македония имеет проблемы и с другими соседями. До сих пор не налажены дипломатические отношения с Сербией. Камнем преткновения являются внешнеполитические (евро-атлантические) ориентации Македонии и подчинение македонской политической элиты курсу США на Балканах по албанскому вопросу и косовской проблеме. Вторым узлом противоречий между македонской и сербской нациями стала религиозная сфера. Сейчас между православными Сербией и Македонией фактически отсутствует единое духовно-религиозное пространство (об остроте конфликта свидетельствует тот факт, что сербские священники до последнего времени не допускались на территорию Маке- 
донии, даже для проведения служб в сербской общине). Сербская православная церковь не признает статус Македонской православной церкви, которая в 1967 г. отделилась как самовольная автокефалия. Вслед за Сербской патриархией ни одна из официальных православных поместных церквей не признала отделение МПЦ, продолжая считать ее частью СПЦ. По мнению К. Степановой, неканонический характер МПЦ, «оторванной» от другого православного мира, остается одним из самых серьезных препятствий на пути налаживания двусторонних отношений Сербии и Северной Македонии [11].

Совершенно противоположная ситуация с исламом. Налицо не просто близость, а полное духовно-религиозное родство албанцев Косово, южной Сербии и Северной Македонии. Это позволяет предположить, что в случае возрастания роли религиозного фактора в обострении конфликта и межэтнической розни между странами его наиболее вероятно можно будет записать в актив албанской стороны.

\section{Политические факторы}

Важной конфликтогенной проблемой последних лет является политическая активность албанского национального меньшинства, компактно проживающего в приграничных с Албанией и Косово районах Македонии. Требования македонских албанцев, изложенные, например, в Декларации о равноправном статусе албанцев в Македонии (1991 г.), заключаются в получении статуса государствообразующего народа, политической автономии, а также учете албанского языка государственным наряду с македонским, на основе внесения соответствующих поправок в Конституцию. Активные политические процессы среди албанцев Албании и Косово, а также обострение противоречий на религиозной почве активизируют националистически настроенные силы македонских албан- цев для участия в борьбе за «Великую Албанию» (включающую западную Македонию, южную Черногорию, часть южной Сербии, Косово и собственно Албанию) или хотя бы за присоединение к Косово. Это, по нашему мнению, ставит под угрозу дальнейшее национально-государственное существование страны и приближает следующую после «независимости Косово» фазу геополитической трансформации на западе Балкан - поглощение «албанским фактором» значительной части Северной Македонии.

K «проблемным» балканским странам принадлежит Босния и Герцеговина. Подписание Дейтонских соглашений в 1995 г. положило конец межэтнической конфронтации на ее территории, но не гарантирует сохранения нынешнего устройства страны как своеобразной конфедерации - Республики Сербской и Мусульмано-хорватской федерации, которые, по оценкам аналитиков, скорее не сотрудничают, а конкурируют друг с другом. За годы после вступления в силу Дейтонского мирного договора во всех трех этногруппах окончательно сформировались собственные политические и военные элиты и чрезвычайно обострилось ощущение национальной обособленности. Дальнейшая этническая самоизоляция, углубление этнически-религиозных разногласий приводят к пробуксовке политико-административных реформ в стране, недееспособности правительства, обострению внутриполитических противоречий и замедлению темпов экономического развития страны. Западные эксперты признают, что сейчас Босния и Герцеговина сохраняется исключительно благодаря мощному влиянию международного сообщества, что, в свою очередь, не исключает возможности присоединения Республики Сербской к Сербии, а хорватской части федерации - к Хорватии. Нестабильность в межнациональных отношениях сказывается на миграционных про- 
цессах в стране, о чем свидетельствует уменьшение доли сербов и хорватов.

В то же время напряженность присутствует и в хорвато-сербских отношениях. Это связано с положением сербов в Хорватии. Они нередко меняют национальность, фамилии, принимают католицизм. Увольнение с работы из-за этнической принадлежности становится обычным делом, что подпитывает «великосербский национализм» на Балканах.

О6 активизации албанского движения и процесса дальнейшей перекройки границ на Балканах (что можно рассматривать как начало нового этапа в истории Балкан) свидетельствуют события последних лет в Косово. Обе стороны косовского конфликта (албанцы и сербы) для оправдания позиций активно эксплуатируют собственную национальную историю. И сербы, и албанцы считают эту землю своей. По мнению отечественного исследователя А. Киссе, территория Косово была центром и колыбелью сербской государственности и поэтому имеет огромное значение для дальнейшего культурно-цивилизационного развития Сербии [12. - С. 201].

Таким образом, современные Балканы характеризуются комбинацией как бывших проблем (межэтническая напряженность, споры из-за границ, терроризм, торговля наркотиками и оружием), так и новых, возникших в результате военных конфликтов (беженцы, вынужденные переселенцы; гуманитарные проблемы, массовая безработица и т.д.). Серьезным препятствием на пути их решения являются:

- отсутствие договорно-правовой базы по регулированию межэтнических отношений;

- применение недемократических методов в решении противоречий между сторонами конфликта;

- доминирование политическихинтересов над правовыми нормами.

На сегодняшний день «миротворцы» добились прекращения открытых боев, но ситуация на Балканах остается взрывоопасной, ведь ни одна международная организация (ООН, ОБСЕ, ЕС и др.) не может решить межэтнические проблемы на Балканах. С другой стороны, «европейская перспектива», обещанная из Брюсселя странам региона, может стать именно тем фактором, где общества, народы имеют шанс найти общие цели и, вероятно, - общее будущее. Юго-Восточная Европа может стать частью единой Европы, как только та будет к этому готова. Все государства региона (за исключением Сербии) с начала 1990-х гг. объявили о намерении интегрироваться в Европейский союз и НАТО. Болгария и Румыния уже стали членами евро-атлантических структур (2004 г. - вступление в НАТО, с 2007 г. - члены ЕС). Северная Македония официально стала членом НАТО В 2020 г. С Албанией, Черногорией и Сербией подписаны, а с Боснией и Герцеговиной парафировано соглашение о6 ассоциации с Евросоюзом, который является основным экономическим партнером большинства балканских стран. Албания и Хорватия вступили в НАTO в 2009 г. Кроме того, Албания, Босния и Герцеговина, Хорватия и Черногория вошли в 2008 г. в состав Средиземноморского союза, создание которого позиционируется как естественное продолжение барселонского процесса - европейского и средиземноморского сотрудничества - и который действует на принципах ротации стран-участников (принцип подобен действующему в ЕС) [13].

\section{Заключение}

Подытоживая, следует отметить, что внешнеполитический фактор и в дальнейшем будет играть ведущую роль в политических и межнациональных процессах на Балканах. Большинство стран Балканского региона выражают единодушное стремление к вступлению в европейские структуры, что 
в перспективе, несомненно, будет способствовать расширению политико-экономического сотрудничества и развитию добрососедских отношений между государствами. Однако вопреки усилиям стран Запада в настоящее время не удалось выработать эффективные механизмы налаживания межнациональных взаимоотношений на Балканах. Кроме того, инклюзивность внешних воздействий во внутренние процессы в странах региона, по нашему мнению, лишь обостряет межнациональные противоречия, не оставляя практически никакой возможности для реального политического диалога и поиска конструктивных решений. Это, прежде всего, объясняется политикой двойных стандартов стран Запада к Балканскому региону. Старая Европа всегда рассматривает Балканы только как свою периферию, сырьевой придаток, буферную зону между Западом и Востоком. Поэтому, на наш взгляд, «европейское будущее» балканских стран в определенной степени будет зависеть, с одной стороны, от грядущей геополитической конфигурации самого ЕС, его экономического развития, внутренней и внешней политики и т.д., с другой - от способности балканских стран реагировать на вызовы современности и соответственно корректировать свою внутреннюю и внешнюю политику. Положительную роль для Балкан может сыграть Россия, учитывая ее давние исторические, культурные, духовные, религиозные связи с балканскими народами. Для этого необходимо расширять взаимодействие на всех уровнях 一дипломатическом, экономическом, культурном, научно-образовательном и др. Это будет способствовать решению внутриполитических проблем и формировать эффективную внешнюю политику.

\section{Литература}

1. Нехамкин В.А. Балканизация как социальный процесс: прошлое и будущее // Социум и власть. — 2013. — № 1 (39). — URL: https://cyberleninka.ru/article/n/balkanizatsiya-kaksotsialnyy-protsess-proshloe-i-buduschee (дата обращения: 10.12.2021).

2. Гаджиев К.С. Политическая философия [Текст] / К.С. Гаждиев. - М.: Экономика, 1999.

3. Хантингтон С. Столкновение цивилизаций / С. Хантингтон; [пер. с англ. Велимеев Т., Новиков Ю.]. - М.: АСТ, 2017. - 603 С.

4. King R. Editorial Introduction: Migration in the Western Balkans - Trends and Challenges // Journal of Balkan and Near Eastern Studies. - 2019. - Vol. 21. - No. 1. - P. 1-10. — URL: https://doi.org/10.1080/19448953.2018.1532682.

5. Романенко С.А. Постъюгославское пространство 1992-2014 гг.: проблемы национального самоопределения и непризнанных государств // Актуальные проблемы Европы. 2019. - № 1. - C. 154-171.

6. Conclusions on Croatia (extract from the Communication from the Commission to the Council and the European Parliament «Enlargement Strategy and Main Challenges 2010-2011», $\operatorname{COM(2010)} 660$ final). — URL: http://ec.europa.eu/enlargement/pdf/key_documents/2010/ package/conclusions_croatia_en.pdf (дата обращения: 10.09.2021).

7. Энтина Е.Г. Россия на Балканах: сквозь призму веков к противоречиям современности // Балканы и Россия: 140 лет спустя: материалы международной научной конференции. М., 2019. - С. 290-299.

8. Пономарева Е.Г.Политическое развитие постъюгославского пространства (внутренние и внешние факторы). - М.: МГИМО-Университет, 2017. — 235 с.

9. Игрицкий Ю.И. Восточная Европа: 20 лет социальной трансформации / Ю.И. Игрицкий, Л.Н. Шаншиева - М.: Институт научной информации по общественным наукам РАН, 2017. - 198 c.

10. Арбатова Н.К. Три измерения постсоветских «замороженных» конфликтов // Мировая экономика и международные отношения. - 2019. - T. 63. —№ 5. - C. 88-100. — URL: https://doi.org/10.20542/0131-2227-2019-63-5-88-100. 
11. Степанова Е.А. Религиозный фактор в македонском конфликте // Независимая газета. - 2001. — № 155. — 23 августа.

12. Киссе А.И. Этнический конфликт: теория и практика управления. Политологический анализ: Монография / А.И. Киссе. - М.: Логос, 2016. - 380 с.

13. Belloni R. The Rise and Fall of Peacebuilding in the Balkans. Cham, 2020. - 250 p. - URL: https://doi.org/10.1007/978-3-030-14424-1. 